\title{
Uji Efektivitas Ekstrak Rimpang Kunyit dan Perasan Jeruk Nipis Terhadap Pertumbuhan Staphylococcus aureus
}

\author{
Nurhidayanti ${ }^{1}$, Tri Avenda Islami ${ }^{2}$ \\ ${ }^{1,2}$ Program Studi DIV Teknologi Laboratorium Medis IKesT Muhammadiyah Palembang
}

\begin{abstract}
Abstrak
Salah satu cara untuk menghambat pertumbuhan bakteri Staphylococcus aureus yaitu menggunakan rimpang kunyit (Curcuma demostica Val) dan perasan jeruk nipis (Citrus aurantifolia). Tujuan penelitian ini adalah untuk mengetahui pengaruh pemberian ekstrak rimpang kunyit (Curcuma demostica Val) dan perasan jeruk nipis (Citrus aurantifolia) terhadap pertumbuhan bakteri Staphylococcus aureus. Jenis penelitian yaitu eksperimen, dengan menggunakan metode Posttest-Only Control Design. Sampel Penelitian sebanyak 54 sampel. Penelitian ini dilakukan di Balai Besar Laboratorium Kesehatan (BBLK) Palembang. Hasil dari penelitian ini didapatkan ekstrak rimpang kunyit (Curcuma demostica Val) dapat membentuk zona hambat pada konsentrasi $100 \%$, sedangkan untuk perasan jeruk nipis (Citrus aurantifolia) tidak terbentuk zona hambat bakteri. Hasil uji statistik Mann-Whitney Test didapatkan sebesar 0.000 artinya terdapat perbedaan antara ekstrak rimpang kunyit (Curcuma demostica Val) dan perasan jeruk nipis (Citrus aurantifolia) terhadap pertumbuhan bakteri Staphylococcus aureus. Ekstrak rimpang kunyit (Curcuma demostica Val) dan perasan jeruk nipis (Citrus aurantifolia) bisa digunakan sebagai obat alternative untuk mengobati infeksi yang disebabkan oleh Staphylococcus aureus tetapi belum bisa menggantikan antibiotik.
\end{abstract}

Kata Kunci : Rimpang kunyit, Jeruk nipis, Staphylococcus aureus

\section{Test The Effectivess of Tumeric Rhizome Extract and Lime Juice Against the Growth of Staphylococcus aureus}

\begin{abstract}
One way to inhibit the growth of Staphylococcus aureus bacteria is to use the rhizome of turmeric (Curcuma demostica Val) and lime (Citrus aurantifolia). The purpose of this study was to determine the effect of turmeric (Curcuma demostica Val) and lime (Citrus aurantifolia) rhizome extracts on the growth of Staphylococcus aureus bacteria. This type of research is an experiment using the Posttest-Only Control Design method. The research sample is 54 samples. This research was conducted at the Central Health Laboratory (BBLK) Palembang. The results of this study showed that turmeric (Curcuma demostica Val) rhizome extract could form an inhibition zone at a concentration of $100 \%$, while for lime juice (Citrus aurantifolia) no bacterial inhibition zone was formed. The results of the Mann-Whitney Test statistical test were obtained at 0.000, meaning that there was a difference between extracts of turmeric rhizome (Curcuma demostica Val) and lime juice (Citrus aurantifolia) on the growth of Staphylococcus aureus bacteria. Extracts of turmeric rhizome (Curcuma demostica Val) and lime juice (Citrus aurantifolia) can be used as alternative medicines to treat infections caused by Staphylococcus aureus but cannot stop antibiotics.
\end{abstract}

Keywords : Turmeric rhicome, Lime, Staphylococcus aureus

Korespondensi: Nurhidayanti, Jurusan Teknologi Laboratorium Medis Institut Ilmu Kesehatan dan Teknologi Muhammadiyah Palembang, e-mail nuri89_yanti@yahoo.com 


\section{Pendahuluan}

Penyakit infeksi disebabkan oleh berbagai mikroorganisme seperti bakteri. Salah satu bakteri penyebab infeksi adalah Staphylococcus aureus (Bayu, 2015). Bakteri Staphylococcus aureus adalah bakteri gram positif yang banyak ditemukan salah satunya pada tubuh manusia. Staphylococcus aureus bakteri normal yang ada pada manusia terdapat di daerah kulit, saluran pernapasan,dan pencernaan (Oktasila, 2019). Staphylococcus aureus ditemukan sebanyak $20-50 \%$ di dalam rongga hidung manusia, pakaian dan benda lain. Staphylococcus aureus dapat bersifat patogen dan invasif dengan menghasilkan enzim koagulase (Dianasari, 2020). Staphylococcus aureus berbentuk bulat, dapat menginfeksi jaringan tubuh yang menyebabkan timbulnya penyakit dengan ciri-ciri yang khas seperti nekrosis, peradangan dan pembentukan abses (Oktasila, 2019).

Staphylococcus aureus bersifat nonmotil, nonspora, anaerob fakultatif, katalase positif dan oksidase negatif. Staphylococcus aureus tumbuh pada suhu $6,5-46^{\circ} \mathrm{C}$ dan pada pH 4,2-9,3 (Krishna, 2013). Staphylococcus aureus bertahan hidup pada lingkungan yang mengandung garam dengan konsentrasi yang tinggi. Staphylococcus aureus mudah berkembangbiak karena dapat tumbuh pada suhu sekitar $30^{\circ} \mathrm{C}$ (Magani, 2020). Staphylococcus aureus dapat tumbuh pada makanan, atau minuman yang sudah terkontaminasi. Staphylococcus aureus akan lebih berkembang pada lingkungan yang kotor dan tercemar. Staphylococcus aureus resisten terhadap antibiotik sehingga dalam pengobatannya sulit ditemukan obat yang cocok.

Banyak masyarakat Indonesia memanfaatkan tumbuh-tumbuhan sebagai bahan obat tradisional untuk mengobati sakit yang disebabkan oleh bakteri tersebut. Salah satu tumbuhan yang biasa dijadikan bahan untuk pembuatan obat tradisional yaitu kunyit (Curcuma domestica) yaitu pada bagian rimpangnya (Ulfah, 2020).

Rimpang Kunyit juga bermanfaat sebagai antioksidan untuk menangkal radikal bebas, antibakteri, hipokolesteremik dan mempunyai sifat kolagogum sehingga dapat meningkatkan penyerapan vitamin A, D, E, K (Hidayah, 2020). Kurkuminoid dalam rimpang kunyit merupakan kelompok senyawa fenolik. Reaksi kurkumin sebagai antibakteri mirip dengan senyawa fenol lainnya yaitu dengan cara menghambat metabolisme bakteri dengan merusak membran sitoplasma dan mendenaturasi protein sel yang menyebabkan kebocoran nutrien dari sel sehingga sel bakteri mati atau pertumbuhannya terhambat (Ulfah, 2020).

Selain rimpang kunyit masyarakat juga banyak memenfaatkan Jeruk nipis untuk digunakan sebagai antibakteri. Jeruk Nipis (Citrus aurantifolia) mengandung vitamin $\mathrm{C}$ yang cukup tinggi, jeruk nipis biasanya digunakan untuk mengobati batuk, peluruh dahak (mukolitik), peluruh kencing (diuretik) dan keringat, membantu proses pencernaan, penambah nafsu makan, antipiretik dan antibakteri (Puspita, 2020). Hampir seluruh bagian tanaman jeruk nipis dapat dipakai sebagai agen antibakteri yaitu ekstrak kulit buah, ekstrak daun, ekstrak biji serta air perasannya (Wiswananta, 2019).

Salah satu senyawa kimia pada jeruk nipis yang bersifat antibakteri yaitu tanin. Tanin merupakan senyawa polifenol yang bersifat mengikat, mengendapkan dan menyusutkan protein (Wiswananta, 2019). Dalam perasan jeruk nipis murni mengandung beberapa asam seperti asam sitrat 6,15\%, asam laktat 0,09\%, dan sejumlah asam tartarat. Selain itu terdapat juga sejumlah asam organik seperti asam malat (Berlian, 2016). Dari asam dan zat kimia yang dihasilkan oleh jeruk nipis dapat berfungsi sebagai antibakteri. Perasan jeruk nipis juga digunakan sebagai penghambat pertumbuhan bakteri seperti Escherichia coli, Pseudomonas aureginosa, Stapylococcus aureus, Aspergillus nigerdan Candida albicans (Wiswananta, 2019).

Penelitian ini bertujuan untuk mengetahui pengaruh pemberian ekstrak rimpang kunyit (Curcuma demostica Val) dan perasan jeruk nipis (Citrus aurantifolia) terhadap pertumbuhan bakteri Staphylococcus aureus. Adapun manfaat penelitian ini yaitu masyarakat diharapkan dapat memanfaatkan tumbuhan disekitar lingkungan sebagai bahan alternatif untuk antibiotik.

\section{Metode}

Jenis penelitian yang digunakan adalah Eksperimen. Penelitian ini dilakukan pada tanggal 15-20 Maret 2021 bertempat di Balai Besar Laboratorium Kesehatan (BBLK) Palembang. Sampel yang digunakan sebanyak 54 sampel. Dengan menggunakan Posttest-Only Control Design. 
Penelitian ini diawali dengan proses sterilisasi, prosedur kerja proses sterilisasi alatalat gelas, dilanjutkan dengan pembuatan media dengan cara Serbuk media MHA ditimbang sebanyak $17 \mathrm{~g}$ dan dimasukkan ke dalam gelas kimia $500 \mathrm{ml}$, kemudian ditambahkan aquades sebanyak $500 \mathrm{ml}$ kemudian dipanaskan di atas hot plate. Selanjutnya media disterilkan dengan menggunakan autoklaf pada suhu $121^{\circ} \mathrm{C}$ selama 15 menit dan tuangkan pada cawan petridish (Rahmawati, 2014). Kemudian pembuatan suspensi bakteri yaitu Satu ose kultur bakteri dari biakan murni bakteri uji tersebut disuspensikan dalam larutan $\mathrm{NaCl} 0,9 \%$ pada tabung reaksi steril. Kemudian suspensi bakteri divorteks hingga homogen sampai diperoleh kekeruhan sesuai standar Mc Farland atau sebanding dengan jumlah bakteri $1 \mathrm{X}$ $10^{8} \mathrm{CFU} / \mathrm{ml}$ (Berlian, 2016).

Pembuatan perasan jeruk nipis yaitu Jeruk nipis dipotong menjadi 2 bagian. kemudian, peras airnya kedalam tabung erlenmeyer lalu disaring menggunakan kertas saring sampai didapatkan cairan sebanyak $5 \mathrm{ml}$. Penentuan konsentrasi jeruk nipis yaitu dengan menggunakan rumus pengenceran V1 x M1 = V2 x M2 (Berlian, 2016). Pembuatan ekstrak rimpang kunyit dengan cara Rimpang kunyit yang akan digunakan dicuci terlebih dahulu dengan meggunakan air mengalir kemudian di tiriskan. Rimpang kunyit yang sudah bersih dilakukan sortasi basah. Rimpang kunyit dirajang dan dilakukan pengeringan pada suhu $40^{\circ} \mathrm{C}$ di dalam oven. Simplisia rimpang kunyit dibuat serbuk jika sudah kering dengan cara diblender (Wahyu, 2020).

Proses pembuatan ekstraksi dari rimpang kunyit yaitu Pelarut etanol 96\% digunakan dalam proses ekstraksi dengan metode maserasi. 150 gram serbuk simplisia rimpang kunyit ditambahkan pelarut etanol 96\% sebanyak $450 \mathrm{~mL}$ dan dilakukan maserasi. Setelah seluruh serbuk direndam kemudian dilakukan pengadukan secara perlahan dan direndam selama 3 hari dengan dilakukan pengadukan. Maserat yang dihasilkan kemudian diuapkan dengan rotary evaporator pada suhu $50^{\circ} \mathrm{C}$ dan diuapkan sampai menjadi ekstrak kental (Wahyu, 2020).

Uji antibakteri dilakukan secara invitro dengan menggunakan metode difusi cakram, cakram yang digunakan adalah kertas cakram khusus dengan diameter $5 \mathrm{~mm}$. Pengukuran antibakteri berdasarkan zona hambat yang dihasilkan oleh ekstrak terhadap biakan bakteri di media agar. Cakram tersebut dimasukkan ke dalam cawan petri yang berisi biakan bakteri.
Dalam satu cawan petri terdapat lima cakram yang terdiri dari kontrol positif yaitu antibiotik Ciprofloxacin untuk Staphylococus aureus, cakram kedua berisi kontrol negatif yaitu Aquades dan cakram keempat dan kelima yaitu ekstrak yang akan diuji. Plat MHA (Muller Hinton agar) lalu ditutup dan diinkubasi secara aerob pada suhu $37^{\circ} \mathrm{C}$ dengan waktu 24 jam. Adanya potensi sifat antibakteri ekstrak ditentukan dari zona bening di sekitar cakram (Ulfah, 2020). Disk blank yang digunakan pada penelitian ini berdiameter $6,0 \mathrm{~mm}$.

Analisa data menggunakan SPSS 16.0 dengan uji $\mathrm{T}$ Independen taraf kepercayaan sebesar $95 \%$ dengan 0,05 .

\section{Hasil}

Penelitian ini menggunakan tiga kelompok perlakuan, kelompok kontrol positif dan kelompok kontrol negatif. Tiga kelompok perlakuan tersebut masing-masing menggunakan konsentrasi yaitu 50\%, 75\%, dan $100 \%$. Kelompok kontrol positif menggunakan Ciprofloxacin dan untuk kelompok kontrol negatif menggunakan aquades. Hasil penelitian sebagai berikut :

Tabel 1. Hasil Uji Strain Bakteri

\begin{tabular}{ll}
\hline \multicolumn{1}{c}{ Uji } & \multicolumn{1}{c}{ Hasil } \\
\hline Koagulase & Aglutinasi + \\
\hline Pewarnaan Gram & Gram + Coccus + \\
\hline
\end{tabular}

Pada tabel 1 diatas menunjukan hasil tes koagulase pada bakteri Staphylococcus aureus yaitu positif $(+)$ dengan terbentuknya aglutinasi pada slide. Uji koagulase dilakukan untuk mendeteksi pembentukan enzim koagulase yang terikat ke dinding sel bakteri (Jiwintarum, 2015). Hasil pewarnaan gram yaitu bakteri Staphylococcus aureus termasuk kedalam gram positif (+) dengan bentuk coccus positif $(+)$ yang berwarna ungu(Nurnasari, 2019).

Warna ungu pada bakteri dikarenakan bakteri mampu mempertahankan warna kristal violet. Bakteri gram positif kandungan peptidoglikan lebih tebal jika dibandingkan dengan bakteri gram negatif (Nurnasari, 2019). Hasil zona hambat pada media yaitu : 


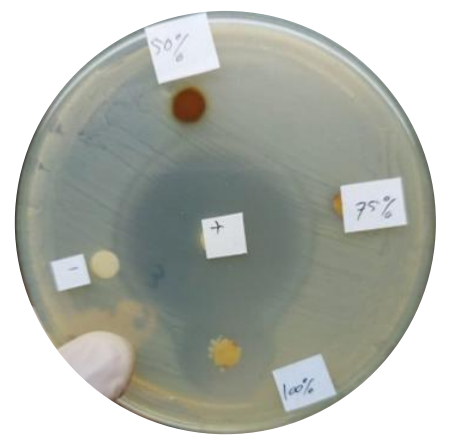

Gambar 1. Hasil Zona Hambat dengan Rimpang Kunyit

Gambar 1 diatas menunjukkan zona hambat bakteri Staphylococcus aureus yang terbentuk hanya pada konsentrasi $100 \%$ menggunakan ekstrak rimpang kunyit.

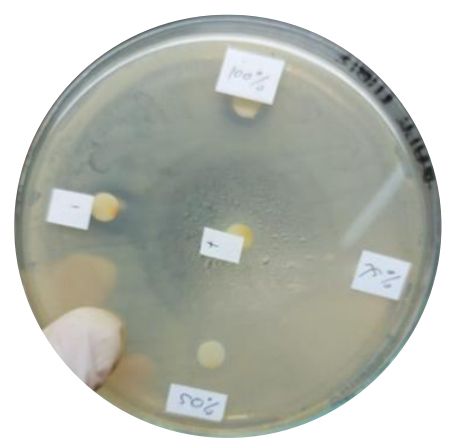

Gambar 2. Hasil Zona Hambat Dengan Perasan Jeruk Nipis

Gambar 2 diatas menunjukan tidak terbentuknya zona hambat bakteri baik pada konsentrasi 100\%, 75\% dan 50\%.

Tabel 2. Hasil Pengukuran Zona Hambat Dengan Ekstrak Rimpang Kunyit

\begin{tabular}{ccccc}
\hline \multirow{2}{*}{ Ulangan } & $\begin{array}{c}\text { Kontrol } \\
(+)\end{array}$ & \multicolumn{3}{c}{$\begin{array}{c}\text { Konsentrasi ekstrak } \\
\text { kunyit(mm) }\end{array}$} \\
\cline { 3 - 5 } 1 & 25 & $\mathbf{1 0 0 \%}$ & $\mathbf{7 5 \%}$ & $\mathbf{5 0 \%}$ \\
\hline 2 & 25 & 7,5 & $\begin{array}{c}\text { Tidak } \\
\text { ada }\end{array}$ & $\begin{array}{c}\text { Tidak } \\
\text { ada }\end{array}$ \\
\hline 3 & 25 & 6,0 & $\begin{array}{c}\text { Tidak } \\
\text { ada }\end{array}$ & $\begin{array}{c}\text { Tidak } \\
\text { ada }\end{array}$ \\
\hline 4 & 25 & 6,0 & $\begin{array}{c}\text { Tidak } \\
\text { ada }\end{array}$ & $\begin{array}{c}\text { Tidak } \\
\text { ada }\end{array}$ \\
\hline 5 & 25 & $\begin{array}{c}\text { Tidak } \\
\text { ada }\end{array}$ & $\begin{array}{c}\text { Tidak } \\
\text { ada }\end{array}$ & $\begin{array}{c}\text { Tidak } \\
\text { ada }\end{array}$ \\
\hline 6 & 25 & $\begin{array}{c}\text { Tidak } \\
\text { ada }\end{array}$ & $\begin{array}{c}\text { Tidak } \\
\text { ada }\end{array}$ & $\begin{array}{c}\text { Tidak } \\
\text { ada }\end{array}$ \\
\hline 7 & 25 & $\begin{array}{c}\text { Tidak } \\
\text { ada }\end{array}$ & $\begin{array}{c}\text { Tidak } \\
\text { ada }\end{array}$ & $\begin{array}{c}\text { Tidak } \\
\text { ada }\end{array}$ \\
\hline 8 & 25 & $\begin{array}{c}\text { Tidak } \\
\text { ada }\end{array}$ & $\begin{array}{c}\text { Tidak } \\
\text { ada }\end{array}$ & $\begin{array}{c}\text { Tidak } \\
\text { ada }\end{array}$ \\
\hline Rata- & 25 & $\begin{array}{c}\text { Tidak } \\
\text { ada }\end{array}$ & $\begin{array}{c}\text { Tidak } \\
\text { ada }\end{array}$ & $\begin{array}{c}\text { Tidak } \\
\text { ada }\end{array}$ \\
\hline 9 & 25 & $\begin{array}{c}\text { Tidak } \\
\text { ada }\end{array}$ & $\begin{array}{c}\text { Tidak } \\
\text { ada }\end{array}$ \\
\hline & & & &
\end{tabular}

Tabel 2 diatas menunjukan hasil pengukuran zona hambat dengan menggunakan ekstrak rimpang kunyit hanya terbentuk pada konsentrasi $100 \%$ dengan rata-rata zona yang terbentuk yaitu $6,75 \mathrm{~mm}$.

Tabel 3. Hasil Pengukuran Zona Hambat Dengan Perasan Jeruk Nipis

\begin{tabular}{ccccc}
\hline Ulangan & $\begin{array}{c}\text { Kontrol } \\
(+)\end{array}$ & \multicolumn{2}{c}{$\begin{array}{c}\text { Konsentrasi ekstrak } \\
\text { kunyit(mm) }\end{array}$} \\
\cline { 3 - 5 } 1 & 25 & $\begin{array}{c}\text { To0\% } \\
\text { ada }\end{array}$ & $\begin{array}{c}\text { 75\% } \\
\text { Tidak } \\
\text { ada }\end{array}$ & $\begin{array}{c}\text { Tidak } \\
\text { ada }\end{array}$ \\
\hline 2 & 25 & $\begin{array}{c}\text { Tidak } \\
\text { ada }\end{array}$ & $\begin{array}{c}\text { Tidak } \\
\text { ada }\end{array}$ & $\begin{array}{c}\text { Tidak } \\
\text { ada }\end{array}$ \\
\hline 3 & 25 & $\begin{array}{c}\text { Tidak } \\
\text { ada }\end{array}$ & $\begin{array}{c}\text { Tidak } \\
\text { ada }\end{array}$ & $\begin{array}{c}\text { Tidak } \\
\text { ada }\end{array}$ \\
\hline 4 & 25 & $\begin{array}{c}\text { Tidak } \\
\text { ada }\end{array}$ & $\begin{array}{c}\text { Tidak } \\
\text { ada }\end{array}$ & $\begin{array}{c}\text { Tidak } \\
\text { ada }\end{array}$ \\
\hline 5 & 25 & $\begin{array}{c}\text { Tidak } \\
\text { ada }\end{array}$ & $\begin{array}{c}\text { Tidak } \\
\text { ada }\end{array}$ & $\begin{array}{c}\text { Tidak } \\
\text { ada }\end{array}$ \\
\hline 6 & 25 & $\begin{array}{c}\text { Tidak } \\
\text { ada }\end{array}$ & $\begin{array}{c}\text { Tidak } \\
\text { ada }\end{array}$ & $\begin{array}{c}\text { Tidak } \\
\text { ada }\end{array}$ \\
\hline 7 & 25 & $\begin{array}{c}\text { Tidak } \\
\text { ada }\end{array}$ & $\begin{array}{c}\text { Tidak } \\
\text { ada }\end{array}$ & $\begin{array}{c}\text { Tidak } \\
\text { ada }\end{array}$ \\
\hline 8 & 25 & $\begin{array}{c}\text { Tidak } \\
\text { ada }\end{array}$ & $\begin{array}{c}\text { Tidak } \\
\text { ada }\end{array}$ & $\begin{array}{c}\text { Tidak } \\
\text { ada }\end{array}$ \\
\hline Rata- & 25 & $\begin{array}{c}\text { Tidak } \\
\text { ada }\end{array}$ & $\begin{array}{c}\text { Tidak } \\
\text { ada }\end{array}$ & $\begin{array}{c}\text { Tidak } \\
\text { ada } \\
\text { ada }\end{array}$ \\
\hline
\end{tabular}

Tabel 3 diatas menunjukan tidak ada zona hambat yang terbentuk karena disk blank yang terbentuk memiliki diameter dibawah 6,0 mm yang artinya tidak terbentuknya zona hambat bakteri Staphylococcus aureus.

\section{Pembahasan}

Adanya perbedaan zona hambat bakteri Staphylococcus aureus menggunakan ekstrak rimpang kunyit dan jeruk nipis dipengaruhi oleh masing-masing senyawa kimia yang terkandung. Perbedaan zona hambat tersebut dipengaruhi oleh zat yang terkandung pada kedua bahan, seperti pada ekstrak rimpang kunyit (Curcuma demostica Val) dipengaruhi oleh kurkumin dan minyak astiri sedangkan pada perasan jeruk nipis (Citrus aurantifolia) dipengaruhi oleh tanin, flavonoid, alkaloid, saponin, dan fenol.

Pada ekstrak rimpang kunyit zona hambat yang terbentuk hanya pada konsentrasi $100 \%$ sedangkan pada konsentrasi $75 \%$ dan $50 \%$ tidak terbentuk zona hambat.Semakin tinggi konsentrasi ekstrak rimpang kunyit maka semakin besar pula zona hambat yang terbntuk. Besar diameter zona hambat yang terbntuk disebabkan kandungan zat antibakteri yang 
lebih banyak pada konsentrasi yang lebih tinggi (Tuntun, 2016).

Pada ekstrak rimpang kunyit (Curcumademostica Val) dipengaruhi oleh kurkumin dan minyak astiri. Seskuiterpen dalam minyak atsiri kunyit merupakan turunan dari senyawa terpen yang dilaporkan memiliki aktivitas antibakteri yang kuat (Ramadhani, 2017).

Kurkumin memiliki efek antibakteri. Mekanisme antibakteri kurkumin yaitu berikatan dengan protein FtsZ dan menghambat perakitan protofilamen sehingga menekan pembentukan cincin Z. Dengan demikian dapat menghambat sitokinesis dan proliferasi bakteri. Ikatan kurkumin pada peptidoglikan bakteri dapat memicu kerusakan pada dinding dan membran sel hingga akhirnya dapat mengalami lisis pada sel bakteri (Cahyani, 2020).

Pada perasan jeruk nipis tidak terbentuknya zona hambat bakteri Staphylococcus aureus karena rata-rata diameter yang dihasilkan pada konsentrasi $100 \%, 75 \%$ dan $50 \%$ dibawah $6,0 \mathrm{~mm}$. Hal ini diduga senyawa flavonoid pada jeruk nipis tidak cukup untuk merusak membrane sel bakteri sehingga bakteri masih bisa memperbanyak selnya. Zona hambat yang terbentuk tidak memiliki pengaruh yang signifikan bila dibandingkan dengan zona hambat yang terbentuk oleh ekstrak rimpang kunyit.

S. aureus yang tergolong bakteri Gram positif memiliki sekitar $50 \%$ peptidoglikan (murein) lapis tunggal yang membentuk struktur tebal dan kaku, dan asam teikoat yang mengandung alkohol (gliserol atau ribitol) dan fosfat sebagai komponen utama dinding sel, kandungan lipida rendah (sekitar 1 hingga 4\%), serta memiliki susunan dinding sel yang kompak. Bakteri Gram positif memiliki dinding sel dengan lapisan peptidoglikan yang terletak di bagian membran luar lebih tebal dibandingkan dengan bakteri Gram negative (Lestari et al., 2020).

Penelitian ini memperlihatkan bahwa jenis bakteri uji dapat mempengaruhi aktivitas antibakteri, disamping adanya pengaruh konsentrasi zat yang ditujukkan melalui pembentukan zona hambat. Ada beberapa hal yang perlu diperhatikan yang menyebabkan variasi zona hambatan, antara lain : kemampuan dan laju difusi antibiotik ke dalam media dan interaksinya dengan mikroba uji, jumlah mikroba yang diinokulasikan, laju pertumbuhan mikroba uji, tingkat kerentanan mikroba uji terhadap antibiotic (Lestari et al., 2020)

Suatu bahan antibakteri alami yang terkandung di dalam tumbuhan dapat dikatakan efektif apabila dalam konsentrasi rendah, zat /bahan tersebut mampu menghambat pertumbuhan bakteri sebanding dengan kemampuan antibakteri standar antibiotika yang digunakan (Lestari et al., 2020). Dalam penelitian ini diketahui bahwa ekstrak rimpang kunyit dengan konsentrasi $100 \%$ baru dapat menghambat pertumbuhan bakteri yang apabila dibandingkan dengan perasan jeruk nipis tidak menunjukkan adanya kesetaraan.

Hasil uji normalitas didapatkan salah satu data tidak terdistribusi normal, maka uji dilanjutkan dengan Mann-Whitney Test.

Tabel 4. Hasil Uji Mann-Whitney Test

\begin{tabular}{|c|c|c|c|c|c|c|}
\hline & & \multicolumn{5}{|c|}{ Mann-Whitney Test } \\
\hline & & \multicolumn{3}{|c|}{ Mean } & \multirow{2}{*}{ Df } & \multirow{2}{*}{ Sig } \\
\hline & & $100 \%$ & $75 \%$ & $50 \%$ & & \\
\hline \multirow{2}{*}{$\begin{array}{l}\text { Zona } \\
\text { Hambat }\end{array}$} & $\begin{array}{c}\text { Ekstrak } \\
\text { Rimpang } \\
\text { Kunyit }\end{array}$ & 14.00 & 5.00 & 5.00 & 27 & \multirow{2}{*}{.000} \\
\hline & $\begin{array}{c}\text { Perasan } \\
\text { Jeruk } \\
\text { Nipis } \\
\end{array}$ & 13.50 & 7.00 & 5.50 & 27 & \\
\hline
\end{tabular}

Tabel 4 diatas menunjukan hasil setelah dilakukan uji Mann-Whitney Test yaitu sig .000 yang artinya mempunyai perbedaan yang bermakna antara konsentrasi yang diberikan.

Hasil penelitian ini sejalan dengan penelitian yang dilakukan oleh Ramadhani (2017) dengan penelitiannya yang berjudul Hambat ekstrak etanol rimpang kunyit (Curcuma demostica V.) terhadap pertumbuhan bakteri Staphylococcus aureus secara in vitro menyimpulkan bahwa ekstrak etanol rimpang kunyit (Curcuma demostica V.) memiliki daya hambat terhadap pertumbuhan bakteri Staphylococcus aureus dengan konsentrasi paling efektif yaitu $80 \%$, ekstrak etanol rimpang kunyit (Curcuma demostica V.) dapat digunakan sebagai alternatif pengganti antibiotik terhadap infeksi oleh bakteri Staphylococcus aureus.Dengan hasil uji statistik menunjukan nilai $\rho=0,001 \quad(\rho<0,05)$ yang berarti terdapat perbedaan yang bermakna antara konsentrasi yang diberikan.

Penelitian ini juga sejalan dengan Fadillah (2020) Uji efektivitas kunyit putih (Curcuma spp) terhadap pertumbuhan Escherichia coli dengan konsentrasi paling efektif yaitu $100 \%$. Dengan hasil uji statistik menunjukan nilai $\rho=0,001 \quad(\rho<0,05)$ yang artinya terdapat perbedaan yang bermakna dari 
antara konsentrasi yang diberikan dan penelitian yang dilakukan sejalan juga dengan penelitian yang dilakukan Cahyani (2020) Uji efektivitas antibakteri ekstrak rimpang kunyit (Curcuma demostica Val) terhadap pertumbuhan Propionibacterium acnes in vitro dengan konsentrasi tertinggi $100 \%$ dan hasil uji statistik $\rho=0,000(\rho<0,05)$ sehingga terdapat perbedaan yang bermakna dari konsentrasi yang diberikan.

Penelitian ini sejalan dengan Razak (2013) dengan penelitiannya Uji daya hambat air perasan buah jeruk nipis (Citrus aurantifolia) terhadap pertumbuhan bakteri Staphylococcus aureus secara in vitro mempunyai daya hambat terhadap pertumbuhan bakteri Staphylococcus aureus dengan konsentrasi tertinggi $100 \%$, dimana semakin tinggi konsentrasi yang diberikan maka semakin besar pula daya hambatnya terhadap bakteri Staphylococcus aureus.

Penelitian ini juga sejalan Kusumawati (2018) Uji efektivitas air perasan jeruk nipis (Citrus aurantifolia) dan madu randu dalam menghambat pertumbuhan bakteri Propionibacterium acnes dengan konsentrasi tertinggi $100 \%$. Dengan hasil uji statistik $\rho=$ 0,05 artinya terdapat perbedaan yang bermakna dari konsentrasi yang digunakan. Penelitian yang dilakukan juga sejalan dengan penelitian yang dilakukan oleh Wiswananta (2019) Uji efektivitas antibakteri ekstrak buah jeruk nipis (Citrus aurantifolia) terhadap pertumbuhan Streptococcus mutans in vitro dengan konsentrasi $80 \%$, dan hasil uji statistik $\rho=0,001$ $(\rho<0,05)$ semakin besar konsentrasi yang digunakan semakin besar pula zona hambat yang terbentuk, dan terdapat perbedaan yang bermakna dari konsentrasi yang diberikan.

Simpulan dari penelitian ini yaitu ekstrak rimpang kunyit lebih baik membentuk zona hambat pada bakteri Staphylococcus aureus dibandingkan dengan perasan jeruk nipis. Baik ekstrak rimpang kunyit maupun perasan jeruk nipisbisa digunakan sebagai obat alternative untuk mengobati infeksi yang disebabkan oleh Staphylococcus aureus tetapi belum bisa menggantikan antibiotik. Adapun saran yang dapat diberikan yaitu dapat melakukan penelitian lanjutan dengan menggunakan alternative bakteri lainnya untuk menguji tingkat efektivitas dari rimpang kunyit ataupun perasan jeruk nipis.

\section{Daftar Pustaka}

Bayu Y Kristianto, Indah Sulistyarini, dan Ririn Suharsanti. 2015. Uji aktivitas antibakteri ekstrak etanol, air buncis (Phaseolus vulgaris, L) dan fraksi-fraksinya terhadap pertumbuhan bakteri Staphylococcus aureus. Media Farmasi Indonesia. 14(2).

Berlian Z, Awalul Fatiqin, dan Eka Agustina. 2016. Penggunaan perasan jeruk nipis (Citrus aurantifolia) dalam menghambat bakteri Escherichia coli pada bahan pangan. Jurnal Bioilmi. 2(1).

Bibiana K Ugha, Desi Indria Rini, S.M.J Koamesah. 2019. Uji aktivitas anti bakteri ekstrak etanol daun cengkeh (Syzygium aromaticum.l) terhadap pertumbuhan Escherichia coli secara in vitro.Cendana Medical Journal. 17(2).

Cahyani A, Dwi Indria Anggraini, Tri Umiana Soleha, dan Agustyas Tjiptaningrum. 2020. Uji efektivitas antibakteri ekstrak rimpang kunyit (Curcuma demostica Val) terhadap pertumbuhan Propionibacterium acnes in vitro. Jurnal kesehatan. 11(3).

Chusinah M, Ahmad Muhtadi. 2017. Review artikel : aktivitas jeruk nipis (Citrus aurantifolia) sebagai antibakteri, antivirus, antifungal, larvasida dan athelmintik. Farmaka. 15(2).

Dianasari D, I Wayan Seniarta, dan Moch. Amrun Hidayat. 2020. Potensi ekstrak dan fraksi daun Gardenisa augusta sebagai agen antibakteri terhadap Staphylococcus aureus. Journal of Pharaceutical Care Anwar Medika. 2(2).

Hidayah N, Dyah Widhowati, Retina Yunani, dan Esperanza Sera. 2020. Profil histopatologi hepar ayam yang diinfeksi antigen Avian Influenza (AI) / Flu Burung dan pemberian ekstrak kunyit (Curcuma demostica val).22(1).

Huda M, Rodhiansyah, Devi Sulistia Ningsih. 2018. Efektivitas ekstrak bunga cengkeh (Eugenia aromatica) terhadap pertumbuhan bakteri Staphylococcus aureus. Jurnal Analis Kesehatan. 7(1). 
Jiwintarum Y, Lalu Srigede, dan Auliya Rahmawati. 2015. Perbedaan hasil uji koagulase menggunakan plasma sitrat manusia $3,8 \%$, plasma sitrat domba $3,8 \%$, dan plasma sitrat kelinci 3,8\% pada bakteri Staphylococcus aureus. Jurnal kesehatan prima. 9(2).

Krisnha A Dewi. 2013. Isolasi, identifikasi dan uji sensitivitas Staphylococcus aureus terhadap amoxcillin dari sampel susu kambing peranakan ettawa (PE) penderita mastitis diwilayah Girimulyo, Kulonprogo, Yogyakarta. Jurnal Sain Veteriner. 31(2).

Kusumawati N, Solikah Ana Estikomah, dan Surya Amal. 2018. Uji efektivitas air perasan jeruk nipis (Citrus aurantifolia) dan mandu randu dalam menghambat pertumbuhan bakteri Propionibacterium acnes. Pharmasipha. 2(2).

Lestari, A. L. D., Noverita, \& Permana, A. (2020). DAYA HAMBAT PROPOLIS TERHADAP BAKTERI Staphylococcus aureus DAN Escherichia coli. Jurnal ProLife, 7(3), 237-250.

Magani K. Alce, Trina E. Tallei, dan Beivy J. Kolondam. 2020. Uji antibakteri nanopartikel kitosan terhadap pertumbuhan bakteri Staphylococcus aureus dan Escherichia coli. Jurnal Bios Logos. 10(1).

Ngajow M, Jemmy Abidjulu, Vanda S Kamu. 2013. Pengaruh antibakteri Ekstrak kulit batang matoa (Pometia pinnata) terhadap bakteri Staphylococcus aureus secara in vitro. Jurnal MIPA UNSRAT. 2(2).

Nurnasari E, Kristiana Sri Wijaya. 2019. Aktivitas antibakteri minyak astiri daun tembakau terhadap pertumbuhan bakteri Escherichia coli dan Staphylococcus aureus. Jurnal kefarmasian Indonesia. $9(1)$

Oktasila D, Nurhamidah, dan Dewi Handayani. 2019. Uji aktifitas antibakteri daun jeruk kalamansi (Citrofortunella microcarpa) terhadap bakteri Staphylococcus aureus dan Escherichia coli. Jurnal pendidikan dan ilmu kimia. 3(2).
Puspita W, Hairunnisa, dan Putri Dwi Awaliah. 2020. In vitro antibacterial activity of lime fruit juice (Citrus aurentifolia) on Staphylococcus aureus bacteria. Jurnal ilmiah farmako bahari. 11(1).

Rahmawati. 2014. Interaksi ekstrak daun lidah buaya (Aloe Vera L.) dan daun sirih (Piper Betle L.) terhadap daya hambat Staphylococcus aureus secara In Vitro. Jurnal EduBio Tropika. 2(1) : 121-186.

Ramadhani P, Erly, dan Asterina. 2017. Hambat ekstrak etanol rimpang kunyit (Curcuma demostica Val) terhadap pertumbuhan bakteri Staphylococcus aureus secara In vitro.Jurnal kesehatan Andalas. 6(3).

Razak A, Djamal A, Revilla G. 2013. Uji Daya Hambat Air Perasan Jeruk Nipis (Citrus aurantifolia) Terhadap Pertumbuhan Bakteri Staphylococcus aureus Secara in vitro. Jurnal Kesehatan Andalas. 2(1).

Tuntun, M. (2016). Uji Efektivitas Ekstrak Daun Pepaya (Carica papaya L.) terhadap Pertumbuhan Bakteri Escherichia coli dan Staphylococcus aureus. Jurnal Kesehatan, 7(3), 497.

https://doi.org/10.26630/jk.v7i3.235

Ulfah M. 2020. Aktivitas antibakteria ekstrak aseton rimpang kunyit (Curcuma demostica) terhadap bakteri Staphylococcus aureus dan Escherichia coli. Jurnal farmasi Muhammadiyah kuningan. 5(1).

Wahyu A Ningsih, Iif Hanifah, A'yunil Hisbiyah. 2020. Pengaruh perbedaan metode ekstraksi rimpang kunyit (Curcuma demostica) terhadap rendemen dan skrining fitokimia. Journal of Pharmaceutical Care Anwar Medika. 2(2).

Wiswananta P Parama, I Dewa Made Sukrama, dan Steffano Aditya Handoko. 2019. Uji efektifitas antibakteri ekstrak buah jeruk nipis (Citrus aurantifolia) terhadap pertumbuhan Streptococcus mutans in vitro. Bali dental journal. 3(1) 